\title{
An Uncertain Future for American Lauraceae: A Lethal Threat from Redbay Ambrosia Beetle and Laurel Wilt Disease (A Review)
}

\author{
Paul E. Kendra*, Wayne S. Montgomery, Jerome Niogret, Nancy D. Epsky \\ United States Department of Agriculture, Agricultural Research Service, Subtropical Horticulture Research Station, Miami, USA. \\ Email: *aul.kendra@ars.usda.gov
}

Received January $4^{\text {th }}, 2013$; revised February $11^{\text {th }}, 2013$; accepted February $20^{\text {th }}, 2013$

\begin{abstract}
Laurel wilt is a destructive vascular disease responsible for high mortality of American tree species in the family Lauraceae, particularly redbay (Persea borbonia) and swampbay (P. palustris), two dominant components of Coastal Plain forest communities in the southeastern United States. The disease syndrome emerged as a result of establishment of an exotic wood-boring beetle, Xyleborus glabratus, now known as the redbay ambrosia beetle. During gallery excavation, females of $X$. glabratus introduce a newly-described, obligatory fungal symbiont, Raffaelea lauricola. This fungus proliferates within the gallery and provides food for the beetles, but it has proven to be pathogenic to American lauraceous hosts, which have had no co-evolved history with $R$. lauricola. Presence of the foreign fungus elicits secretion of resins and formation of extensive parenchymal tyloses within xylem vessels. The extreme defensive response results in blockage of water transport, systemic wilt, and ultimately tree death. The beetle vector was first detected near Savannah, Georgia in 2002, and since has spread throughout the Southeast to become established in six states. The epidemic spread south through Florida more rapidly than predicted and currently threatens commercial production of avocado (Persea americana). Recent research indicates that California bay laurel (Umbellularia californica) can serve as a reproductive host for X. glabratus and is susceptible to laurel wilt disease. Thus, the US Pacific coastal forest ecosystems (and the California avocado industry) would be negatively impacted should the vector become established along the western coast. This review article summarizes our current understanding of the insect vector, the mycopathogen, and the susceptible host tree species. It also addresses elements of disease management and limitations with our current detection methods for redbay ambrosia beetle, which rely on manuka oil lures. Of the host-based attractants evaluated, cubeb oil shows the most promise as a potential new lure for X. glabratus.
\end{abstract}

Keywords: Laurel Wilt; Lauraceae; Raffaelea lauricola; Redbay Ambrosia Beetle; Xyleborus glabratus

\section{Introduction}

Laurel wilt is a lethal vascular disease of American tree species in the plant family Lauraceae. Since its introduction into the United States a decade ago, laurel wilt has spread extensively throughout the southeastern Coastal Plain, escalating to epidemic proportions. It has had severe impact on forest ecosystems, decimating large poputions of native Persea trees, notably redbay $[P$. borbonia (L.) Spreng.] and swampbay [P. palustris (Raf.) Sarg.] [1]. With progressive spread southward, the disease now poses an imminent economic threat to the avocado $(P$. americana Mill.) industry in Florida, which is centered in Miami-Dade County [2-4].

Laurel wilt is caused by a fungus, Raffaelea lauricola T. C. Harr., Fraedrich \& Aghayeva (Ophiostomatales:

*Corresponding author.
Ophiostomataceae) [5], that is vectored by an Asian ambrosia beetle, Xyleborus glabratus Eichhoff (Coleoptera: Curculionidae), commonly known in the US as the redbay ambrosia beetle $[1,6]$. Ambrosia beetles (Curculionidae: Scolytinae and Platypodinae) are a diverse, polyphyletic group of wood-boring insects that feed on symbiotic fungi, which they cultivate in galleries within the interior (mostly dead) xylem layers of host trees [7]. The majority of ambrosia beetles are generalists that target dying or dead trees (saprotrophic symbiosis), and therefore contribute to natural decomposition of wood. However, some ambrosia beetles can become serious pests of forestry and agriculture, particularly when introduced into new environments. Due to increased global commerce and the challenges of detecting insect-infested wood materials [8], there has been an accumulation of non-indigenous forest pests in the continental US in re- 
cent decades [9]. In particular, adventive ambrosia beetles are becoming an emerging threat worldwide [10], and $X$. glabratus constitutes the welfth species of nonative ambrosia beetle known to have become established in the US since 1990 [11]. Although benign in its native lands [12], the redbay ambrosia beetle has acquired pest status upon entry into the US, where its symbiotic fungus is pathogenic when introduced into new (naïve) host trees.

\section{Establishment and Spread}

The first redbay ambrosia beetle detected in North America was trapped in May 2002 in Port Wentworth, Georgia, a maritime port near Savannah (Figure 1) [13]. By 2003, extensive mortality of redbay trees had been observed in several counties surrounding Savannah, and by 2004 the association between laurel wilt disease and $X$. glabratus infestation had been documented [1].

Since that time, the geographic range of $X$. glabratus and laurel wilt has expanded at a rate exceeding that calculated from predictive models [14]. The widespread availability of suitable hosts in Florida, most likely coupled with human transport of infested material (e.g. firewood [15]), facilitated rapid southward spread, particularly along the Interstate 95 corridor of Florida's eastern coast. In March 2010, the first redbay ambrosia beetle was trapped in northern Miami-Dade County, five years before the predicted date [14], and laurel wilt disease was detected subsequently in stands of swampbay trees in February 2011 [16] and then in commercial avocado groves in April 2012 [4].

The vector-disease complex has spread more slowly toward the north, and is beginning to progress westward along the Gulf Coast (along Interstate 10). As of August 2012, laurel wilt had been confirmed in portions of North Carolina, South Carolina, Georgia, Florida, Alabama, and Mississippi (Figure 1) [17].

\section{Epidemiology}

Multiple factors contribute to the transmission and expression of laurel wilt disease in forest ecosystems. Although the ecological interactions are complex and

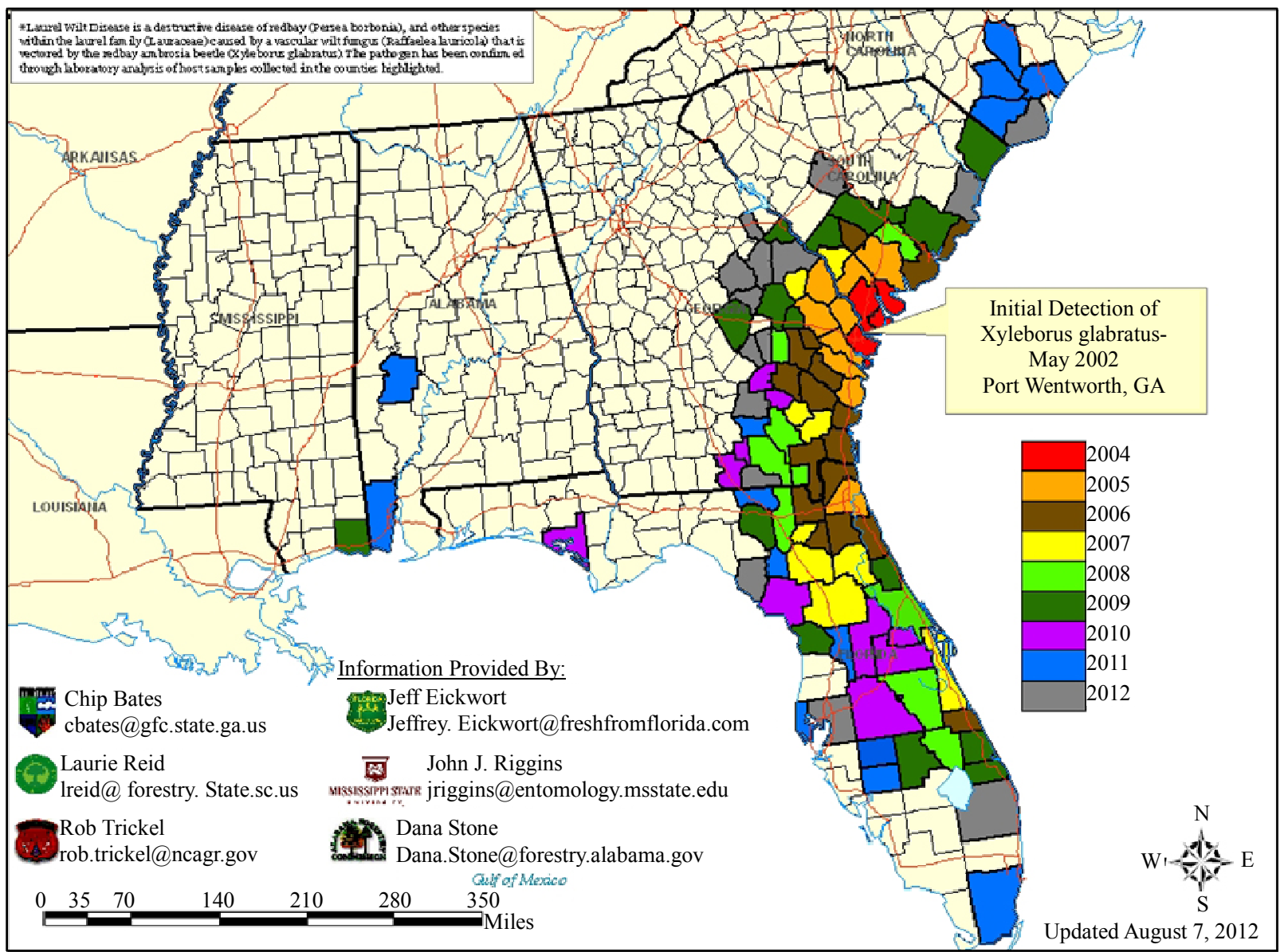

Figure 1. Distribution of laurel wilt disease in the southeastern United States, based on confirmed county records as of August 2012. Compiled by the USDA Forest Service [17]. 
still poorly understood, we know that there is an intimate association among three species: the insect vector, its symbiotic fungus, and a susceptible woody host (however, at the present time we cannot rule out the possibility of pathogen transmission via pruning tools or root grafting between adjacent trees [18]). The general scenario required for disease development is as follows:

- A founding female $X$. glabratus must be able to locate an appropriate host tree and overcome its innate defenses (which may require more than one beetle attack [19]) to bore successfully into the host and excavate a brood gallery.

- The host's internal environment (moisture content, temperature, nutrient levels, secondary chemistry, etc.) must be conducive to growth of the fungal symbiont, which is essential for successful insect reproduction.

- The host tree must recognize the fungus as foreign to induce the defensive response that culminates in laurel wilt symptoms (The underlying mechanisms evoking host response are not yet known).

- The insect progeny must be able to complete their development/maturation and disperse from the natal tree before the internal conditions deteriorate.

\subsection{Insect Vector}

Xyleborus glabratus is the confirmed vector of the pathogen responsible for laurel wilt disease in the US. It is a small ( $\sim 2 \mathrm{~mm}$ in length), cylindrical, shiny black or dark brown wood-boring beetle native to India, Bangladesh, Japan, Myanmar, and Taiwan [13]; however, the beetle has not been associated with tree disease or mortality in these countries [12]. Like other ambrosia beetles in the tribe Xyleborini, $X$. glabratus is known to have extensive inbreeding, haplo-diploid sex determination, and a sex ratio highly skewed toward females [7]. Adult males (Figure 2(a)) are haploid and flightless, are smaller than females with less developed mandibles and compound eyes, and have the pronotum flattened anteriorly and extending over the head capsule to form a "hood" which bears two small blunt horns at the apex. Males rarely leave the gallery and mate with sibling or parental females (consanguineous polygyny). Diploid (typically mated) adult females (Figure 2(b)) emerge from their natal trees and engage in brief dispersal flights during the late afternoon and early evening hours [20,21]. Dispersing female $X$. glabratus carry fungal spores (conidia) in specialized cuticular organs called mycangia, located at the base of each mandible [1]. Once an appropriate host is found, females will bore into the tree and introduce fungal spores while excavating their galleries; thus, only females serve as disease vectors. Galleries are made perpendicular to the tree trunk, and consist of a main en- trance tunnel which branches laterally into secondary and tertiary tunnels (Figure 2(c)) [22]. Females lay eggs at the ends of the secondary and tertiary tunnels (brood galleries) and cultivate fungal gardens along the gallery walls. Both the adults and larvae feed on the symbiotic fungus ("ambrosia") [7]; the host wood is not consumed, but expelled from the gallery, resulting in characteristic "sawdust sticks" protruding from the entry holes (Figure 2(d)). The time required for development from egg to teneral adult is approximately 30 days at $25^{\circ} \mathrm{C}$, but females then spend several additional weeks within the gallery before initiating flight [22].

A key consequence of haplo-diploid sex determination is that $X$. glabratus is able to reproduce even in the absence of mating. If unmated at time of dispersal, an adult female can still locate a new host, start a brood gallery, and lay eggs. Those initial unfertilized (haploid) eggs will give rise to males, with which the parental female can mate to produce a second brood of fertilized eggs. Those diploid eggs will develop into females which in turn, will be able to disperse to colonize new hosts.

Although the developmental biology of $X$. glabratus is similar to that known for other xyleborine ambrosia beetles, behaviorally $X$. glabratus is atypical. It is not a host generalist in the US, but appears to be restricted to members of the Lauraceae $[1,6]$. In Asia, reported hosts include tree species from the Dipteracarpaceae, Fabaceae,
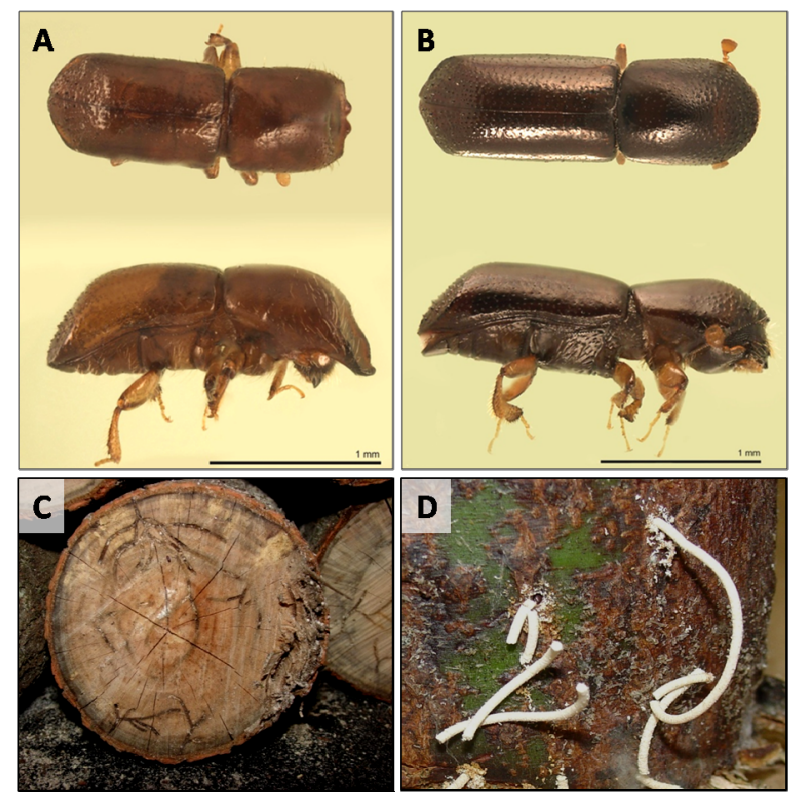

Figure 2. Adult male (A) and female (B) of the redbay ambrosia beetle, Xyleborus glabratus (dorsal view above, lateral view below). (C) Cross-section of trunk from swampbay, Persea palustris, showing galleries formed by $X$. glabratus. (D) Sawdust sticks at beetle entrance holes, indicative of active infestation by ambrosia beetles. 
and Fagaceae, in addition to the Lauraceae [13], suggesting that there has been a behavioral shift in $X$. glabratus that accompanied establishment of populations in the US. Second, X. glabratus does not target stressed or moribund trees, but functions ecologically as a primary colonizer capable of attacking live, apparentlyhealthy hosts [1]. This difference, coupled with its high reproductive potential, has made $X$. glabratus an aggressive invasive pest in American forest ecosystems.

Although at present $X$. glabratus is the only confirmed vector of laurel wilt disease, it is possible that other species of Scolytinae may be associated. Once attacked by $X$. glabratus, stressed trees are susceptible to further attack by secondary colonizers that contribute to the rapid mortality observed in diseased Lauraceae. Since multiple beetle species breed sympatrically within infected trees, the secondary colonizers may potentially pick up Raffaelea spores and transfer them to new trees, thereby accelerating the spread of laurel wilt $[18,23,24]$. In other systems, there is evidence that lateral transfer or 'cross contamination' of symbiotic fungi may occur among ambrosia beetle species that occupy a common breeding site [25]. Alternatively, Raffaelea spores may potentially be transported passively by the setae and cuticular asperities (protuberances) commonly found on the anterior slope of the female pronotum, as has been demonstrated for Hypothenemus hampei (Ferrari) and spores of Fusarium solani (Martius) [26]. There is already preliminary evidence that species other than X. glabratus can carry $R$. lauricola, including Xyloborinus saxesenii (Ratz.) [27], Xyleborus affinis (Eichhoff) [18], and Xyleborus ferrugineus (Fabricius) [18]; however, inoculation of healthy trees by these secondary beetle species has not yet been demonstrated.

\subsection{Fungal Pathogen and Disease Expression}

Raffaelea lauricola is a newly described ambrosia fungus and the confirmed etiologic agent of laurel wilt disease [5]. It is now known to be associated with X. glabratus in both Asia and the United States, indicating that the pathogen was introduced concurrently with the beetle $[28,29]$. Phylogenetically, $R$. lauricola is placed in the Ophiostomatales [30], which includes other known pathogens such as Ophiostoma novo-ulmi, the causal agent of Dutch elm disease. Although R. lauricola is the predominant symbiont, several other fungal species have been isolated from the mycangia of $X$. glabratus, including Ambrosiella, Hyalorhinocladiela, and five other Raffaelea species ( $R$. arxii, R. subalba, R. elliptocospora, $R$. fusca, and $R$. subfusca), but none of these are known to be plant pathogens [31]. This finding indicates that the long-held presumption that ambrosia beetles have close associations with only one or a few symbionts [32] is not accurate, at least for X. glabratus. Recently, it has been shown that $X$. glabratus is attracted to cultures of $R$. lauricola and other ambrosia fungi in short-range laboratory bioassays, suggesting that volatile food-based attractants are emitted from fungal symbionts, but chemical identification of those fungal attractants has yet to be determined [33].

Introduction of $R$. lauricola into susceptible Lauraceae elicits a cascade of events within the host vascular xylem, including secretion of resins and gels, and invagination of parenchymal cells to form tyloses (walls within the xylem tubes) [34]. This defensive response (analogous to anaphylaxis in mammals) is an extreme reaction to the foreign infection that has life-threatening consequences. Extensive tylotic formations throughout the vascular system, not physical clogging of vessels with fungus, result in impaired xylem function, loss of water conduction, systemic wilt, and ultimately tree death. Under laboratory conditions, this process can occur in as little as six weeks [2].

Infected trees display a variety of internal and external disease symptoms $[11,18,19]$. Internally, affected sapwood becomes discolored with bluish gray streaking, and dark brown or black staining forms around the beetle entry holes and galleries. Externally, foliar wilt usually begins with the terminal leaves of the crown and then progresses downward (Figure 3(a)). Within several weeks, leaves turn from dull green to purplish to coppery brown (Figure 3(b)). The foliar wilt occurs quickly without formation of an abscission layer, so leaves cling to dead branches for up to one year, fading to a gray color. Since the vector typically initiates boring in the trunk and larger diameter branches (Figure 4(a)), and since the pathogen is carried upward by the vascular xylem from

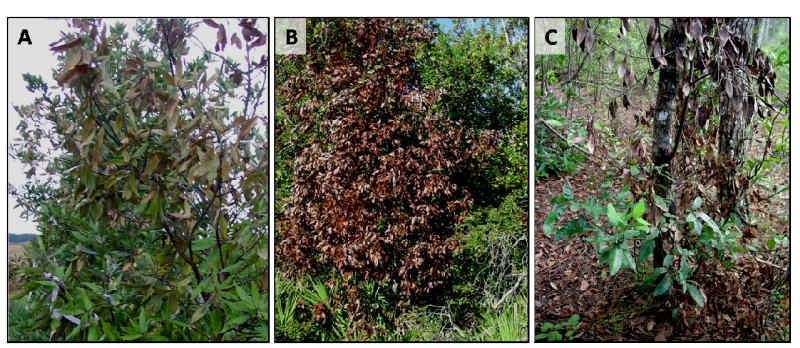

Figure 3. Progression of external symptoms of laurel wilt disease in swampbay, Persea palustris. (A) Foliar wilt typically starts with the terminal leaves in the crown of the tree. (B) Within several weeks of initial symptoms, leaves are dead and turn coppery brown in color. (C) Dead graying leaves cling to the uppermost branches killed first by laurel wilt; newly killed branches bear brown leaves in the middle of the trunk; and new branches sprout from the base of the trunk and flare roots, not yet infected by the mycopathogen, Raffaelea lauricola. 
the point of introduction, the base of the trunk and root system are the last parts of the tree to die; several cycles of regrowth from this region are not uncommon (Figure 3(c)). Another consequence of "diameter-preference" by the vector is that the oldest (largest diameter) trees are typically the first to be attacked by $X$. glabratus and to succumb to laurel wilt disease (Figure 4(b)). Since the external symptoms of laurel wilt may resemble those caused by other biotic and abiotic agents (e.g. lightning strikes, Phytophthora root rot, or Verticillium wilt [18]),
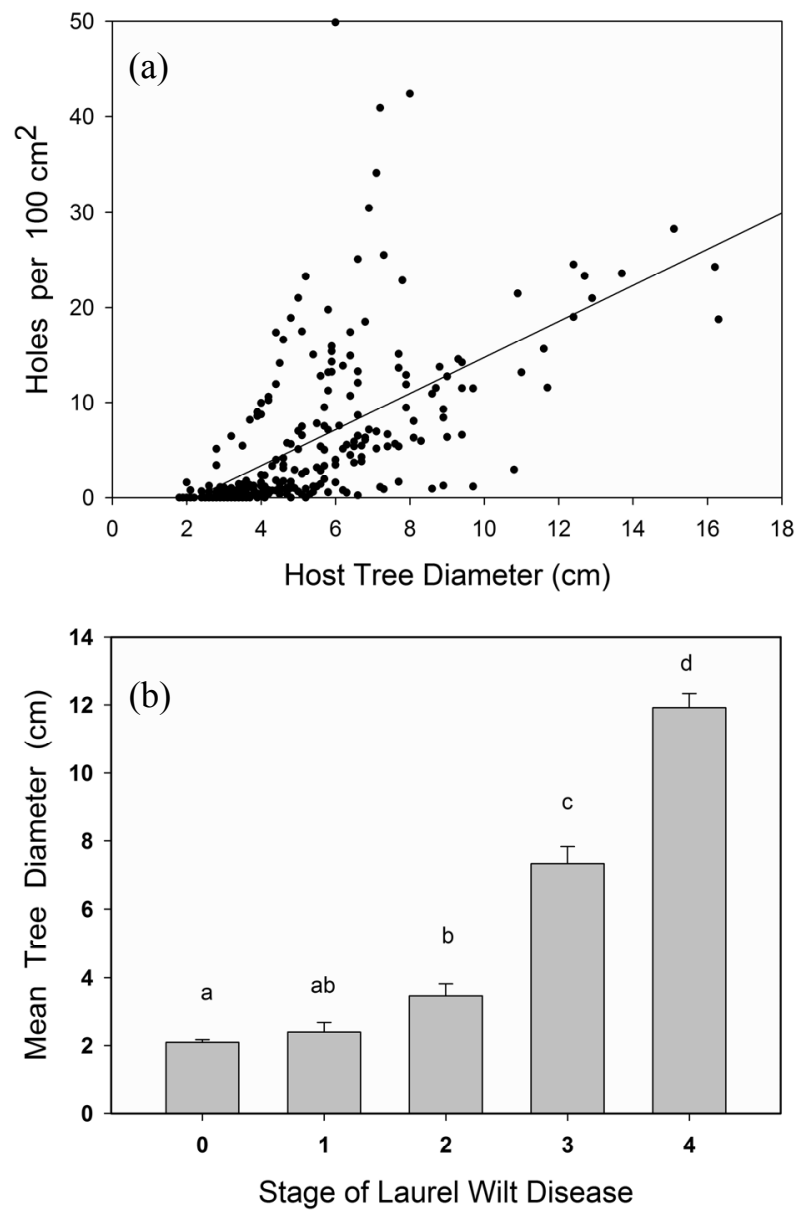

Figure 4. Relationships among host tree diameter, site of Xyleborus glabratus attack, and stage of laurel wilt disease. (a) Number of beetle entrance holes versus the trunk/ branch diameter of host swampbay trees, Persea palustris. 18 intact dead trees were sampled. Each tree was sectioned into $0.5 \mathrm{~m}$ logs, log diameter was measured, bark was stripped, and entrance holes $(0.8 \mathrm{~mm}$ diam [6]) of $X$. glabratus were counted. Counts were then normalized by calculating the number of holes per $100 \mathrm{~cm}^{2}$ surface area (N = 280 data points). (b) Mean diameter of swampbay trees observed for five stages of laurel wilt: 1 = asymptomatic, 2 = wilted green to copper leaves $(<1 \mathrm{yr}), 3=$ gray leaves $(\sim 1 \mathrm{yr})$, $4=$ no leaves $(\sim 2 \mathrm{yr}), 5=$ fallen tree $(\sim 3 \mathrm{yr})$. Tree diameter was measured at $1 \mathrm{~m}$ above ground; $\mathbf{N}=830$ trees surveyed in north-central Florida (Alachua County). definitive diagnosis of the disease requires confirming the presence of Raffaelea using PCR or DNA sequencing techniques. Currently, identification of Raffaelea spp. relies on large subunit ribosomal DNA sequences [28], but development of diagnostic microsatellite sequences is also underway [18].

\subsection{Host Lauraceae}

Eleven US species in the Lauraceae have been reported as hosts of $X$. glabratus and/or shown susceptibility to laurel wilt disease, either in nature (insect vectored) or in the laboratory (by artificial inoculation with the pathogen) $[1,2,6,19,35,36]$. In addition, several other Lauraceae (primarily species of Persea) from outside the US have been evaluated for attraction or boring by $X$. glabratus under experimental conditions [37].

Preferred hosts in the southeastern US are all indigenous species within the genus Persea, with redbay and swampbay populations frequently experiencing mortality in excess of 90 percent within two years of initial attack [1]. Loss of native Persea species has impacted native wildlife [19,38], and in particular has led to a depletion of larval hosts for the palamedes swallowtail butterfly, Papilio palamedes Drury [39]. As the epidemic spreads into central Florida, silkbay ( $P$. humilis Nash) is showing susceptibility to laurel wilt and is dying off throughout the Lake Wales Ridge ecosystem [20]. Silkbay is endemic to Florida and restricted to dry scrub habitats, and taxonomically there is dispute regarding its status as a distinct species or a subspecies of redbay $(P$. borbonia (L.) Spreng. var. humilis (Nash) L. E. Kopp) [40].

In south Florida, laurel wilt has now been positively identified in several commercial avocado groves [4], and the disease also threatens the National Germplasm Repository for avocado in Miami (USDA-ARS, Subtropical Horticulture Research Station). Avocado production represents an estimated \$14 million annually for the state of Florida [41], and the Florida Department of Agriculture and Consumer Services has assembled a Laurel Wilt Working Group to bring together state and federal action agencies, researchers, and growers to address the imminent threat [42]. Recent findings suggest that avocado may be a less suitable reproductive host for $X$. glabratus than is swampbay [24], but once preferred hosts become scarce in south Florida, it is reasonable to assume that there will be strong selection for beetles capable of successful reproduction in avocado wood. Nonetheless, beetle reproduction is not necessary for transmission of the pathogen into avocado, only host recognition and boring by the vector.

Additional hosts identified as susceptible in the southeastern US include sassafras [Sassafras albidum (Nuttall) Nees], camphor tree [Cinnamomum camphora (L.) J. 
Presl] (a non-indigenous tree established in Florida and Georgia), northern spicebush [Lindera benzoin (L.) Blume], lancewood [Ocotea coriacea (Sw.) Britton], pondberry [Lindera melissifolia (Walter) Blume], and pondspice [Litsea aestivalis (L.) Fernald]. The latter two species are listed as endangered at the state and/or federal level [27]. Sassafras and spicebush have a more northern distribution than Persea species, and may facilitate northward expansion of the range of $X$. glabratus if the species is not restricted by temperature limitations. It is not known if $X$. glabratus undergoes diapause, but the species can tolerate hard freezes (it is found as far north as Sampson County, North Carolina, $35^{\circ} \mathrm{N}$ [17]), perhaps due to insulation of beetle galleries within the interior of host trees.

Although breeding populations of $X$. glabratus are only found as far west as Mississippi, experimental research indicates that California bay laurel [Umbellularia californica (Hook \& Arn.) Nutt.] is susceptible to laurel wilt disease when artificially inoculated with $R$. lauricola [43]. In addition, it has just been shown that cut $\operatorname{logs}$ of $U$. californica attract dispersing $X$. glabratus in the field and are capable of supporting beetle reproduction in the laboratory [36]. California bay laurel is a dominant hardwood species along the Pacific Coast of the US (California and Oregon), and should X. glabratus become established in this region, major western forest ecosystems could be devastated. In addition, the avocado Industry in California ( $\$ 415$ million annually [41]) would be threatened, as the native bay laurel could serve as a reservoir for the vector and pathogen (comparable to the situation in south Florida with avocado groves and adjacent swampbay stands).

\section{Disease Management}

Laurel wilt is well established in the southeastern US and its range has now expanded to include the Florida avocado production areas, so eradication of the vector and pathogen is not feasible, and exclusion from unaffected areas will be difficult. Therefore, current efforts should focus on mitigation and management of the disease. The US National Plant Disease Recovery System has compiled separate reports (Recovery Plans) to address the epidemic of laurel wilt in forest ecosystems [19] and in avocado groves [18].

Several management strategies have been adopted and others are currently being evaluated and developed, including limiting transport of potentially infested materials, improving sanitation, and initiating research on insecticides, fungicides, biological control, and host resistance [18]. Specifics on the different approaches are as follows:
- The state of Florida implemented restrictions on the movement of firewood in 2010 to slow long-distance spread of the disease [15], and sanitation recommenddations for avocado growers include prompt identifycation and removal of infected trees (ideally, before the beetle completes its life cycle), and potentially removing native hosts bordering commercial avocado groves [18].

- Initial research shows limited control of X. glabratus with chemical insecticides [44]. Results obtained with contact insecticides were variable, but zeta-cypermethrin + bifenthrin and lambda-cyhalothrin + thiamethoxam provided the most consistent control. Systemic insecticides provided little protection from infestation; this is likely the result of systemic chemicals remaining in the peripheral vascular xylem, whereas active beetle galleries are located within the interior dead xylem (heartwood), inaccessible to the toxicant. In addition, X. glabratus feeds on symbiotic fungi and may ingest little or no host wood, reducing the likelihood of exposure to a lethal dose of insecticide.

- Macro-infusion of host trees with systemic fungicides (e.g. propiconizole) has been shown to successfully confer short-term resistance against $R$. lauricola in both redbay [45] and in avocado [46], but this option has substantial limitations, including prohibitive costs and large-scale implementation. As with insecticide applications, fungicide infusion must be done prophylactically. Once trees are symptomatic for laurel wilt, the xylem vessels are blocked and unable to uptake soluble fungicides. With Dutch elm disease, fungicides have been shown to be ineffective if treatment occurs after more than $20 \%$ of the canopy is affected [47].

- Biological control measures have been developed for management of Dutch elm disease [48] and currently are being evaluated for laurel wilt. An endophytic fungus, Phaeomoniella sp., was found to be associated with healthy redbay trees in an area affected by laurel wilt [49]; the fungus also inhibited growth of $R$. lauricola in vitro, showing promise as a potential agent against laurel wilt.

- Development of resistant cultivars for avocado will be a long-term research endeavor. In no-choice tests, $X$. glabratus bored into all avocado cultivars that have been evaluated thus far $[2,37,50]$, and initial field tests indicated no difference in beetle attraction among the three genetic races of avocado (Mexican, Guatemalan, and West Indian) [50]. Therefore, systematic screening of germplasm by artificial inoculation with $R$. lauricola may be the best approach to identify resistant cultivars for use in breeding pro- 
grams $[3,51]$. In addition, efforts are underway to develop Simple Sequence Repeat (SSR) and Single Nucleotide Polymorphism (SNP) markers to saturate the current avocado genetic linkage maps and to use for association mapping to locate genes involved with tolerance or resistance to the laurel wilt pathogen [52].

The disease management strategies outlined above are more applicable to agricultural ecosystems than to forest habitats. The Recovery Plan for Laurel Wilt on Redbay and Other Forest Species [19], drafted in 2009, acknowledges that we may have to let the disease simply run its natural course in forests. However, it is unlikely that native Persea species like redbay and swampbay will face extinction, for several reasons. First, the beetle vector preferentially attacks large diameter hosts, and bore holes have not been observed in trunks less than $\sim 2$ $\mathrm{cm}$ diameter (Figure 4(a)); second, forest Persea species (unlike avocado) can flower and set fruit at a very young age; and third, $R$. lauricola infection does not progress into the fruit pulp or seed in avocado [53], and presumably this applies to native Persea fruits (drupes) as well. In addition, there is preliminary evidence that some resistance to the disease exists in natural Persea populations in north Florida (J. A. Smith, University of Florida, personal communication). Therefore, the species should persist, although populations may consist of relatively small trees or shrubs in areas where $X$. glabratus resides. In addition to the recommendations above, the Forest Plan includes protecting individual, high-value landscape trees, and considering a germplasm conservation program for threatened hosts, such as pondberry and pondspice. In both forest and agricultural ecosystems, a critical component for curtailing spread of laurel wilt is the development of attractants for early detection and monitoring of $X$. glabratus.

\section{Vector Detection and Monitoring}

Effective detection, monitoring, and control programs for $X$. glabratus are dependent on an understanding of the chemical ecology and host-seeking behaviors of this invasive insect pest. To date, no aggregation or sex pheromones have been indentified for X. glabratus. This is not unexpected since adult females are typically siblingmated prior to dispersal. It is also known that X. glabratus is not attracted to ethanol [6,54], which is the standard lure employed for detection and monitoring of ambrosia beetles in the US [55]. Ethanol is a signature chemical indicative of tree decay, and since $X$. glabratus is a primary colonizer of healthy trees, it does not respond to ethanol as do typical Scolytinae.

Initial research indicated that volatiles (terpenoids) from host Lauraceae are the principal semiochemicalsattractive to dispersing $X$. glabratus [6]. In fact, freshlycut host wood is an ideal bait for collection of live, dispersing females for use in experimental research [56]. Early work also found that manuka oil (essential oil extract from wood of Leptospermum scoparium Forst \& Forst. [Myrtaceae]) and phoebe oil (extract from Phoebe porosa Mex. [Lauraceae]) are good sources of those host-based attractants, and therefore suitable for field lures [57]. Subsequent studies showed that commercially available manuka and phoebe oil lures were non-specific, capturing numerous non-target Scolytinae [23,58]. In addition, manuka lures were not competitive with host Persea wood [50] and had limited longevity (2 - 3 weeks in Florida) due to rapid loss of terpene compounds [58]. Commercial phoebe oil lures were competitive and highly effective for detection of X. glabratus (10 - 12 weeks in Florida) $[50,58]$, but unfortunately they are no longer available due to depletion of source trees in the Brazilian rain forest. Consequently, the current monitoring system for $X$. glabratus in the US consists of the suboptimal manuka oil lure deployed in a Lindgren multi-funnel trap $[59,60]$.

Progress has been made on identification of the specific host-based attractant chemicals (kairomones) from Lauraceae, which are primarily $\mathrm{C}_{15}$ sesquiterpenes. Tentative identifications have been obtained through two lines of evidence. The first consisted of comparative analyses of volatile emissions from attractive essential oils [50,57,58], wood of host Lauraceae [50,57,61], and wood of lychee (Litchi chinensis Sonn. [Sapindaceae], a non-host high in $\alpha$-copaene [62] and found to be highly attractive to female $X$. glabratus in field tests) $[50,61]$ (Figure 5). The second source of evidence was obtained by correlating lure and host emissions with captures of $X$. glabratus in field tests [50,58] (Figure 6). Based on the combined results from these studies, our current hypothesis is that $\alpha$-copaene is the primary long-range attractant, requisite to initiate a behavioral response, but that several other sesquiterpenes are also potentially involved, including $\alpha$-cubebene, $\alpha$-humulene, $\beta$-caryophyllene, $\delta$-cadinene, and calamenene. Thus, it is likely that female $X$. glabratus locate host trees by olfactory detection of a generalized bouquet or "volatile signature" of the Lauraceae, not a single component attractant kairomone [58,61]. Recently, an electrophysiological technique has been developed to quantify olfactory responses from $X$. glabratus [20], and this method will be useful in confirming chemoreception of the specific sesquiterpenes hypothesized to function as kairomones.

Although identification of specific attractant chemicals will be extremely useful information, development of an improved lure using synthetic sesquiterpenes may not be 


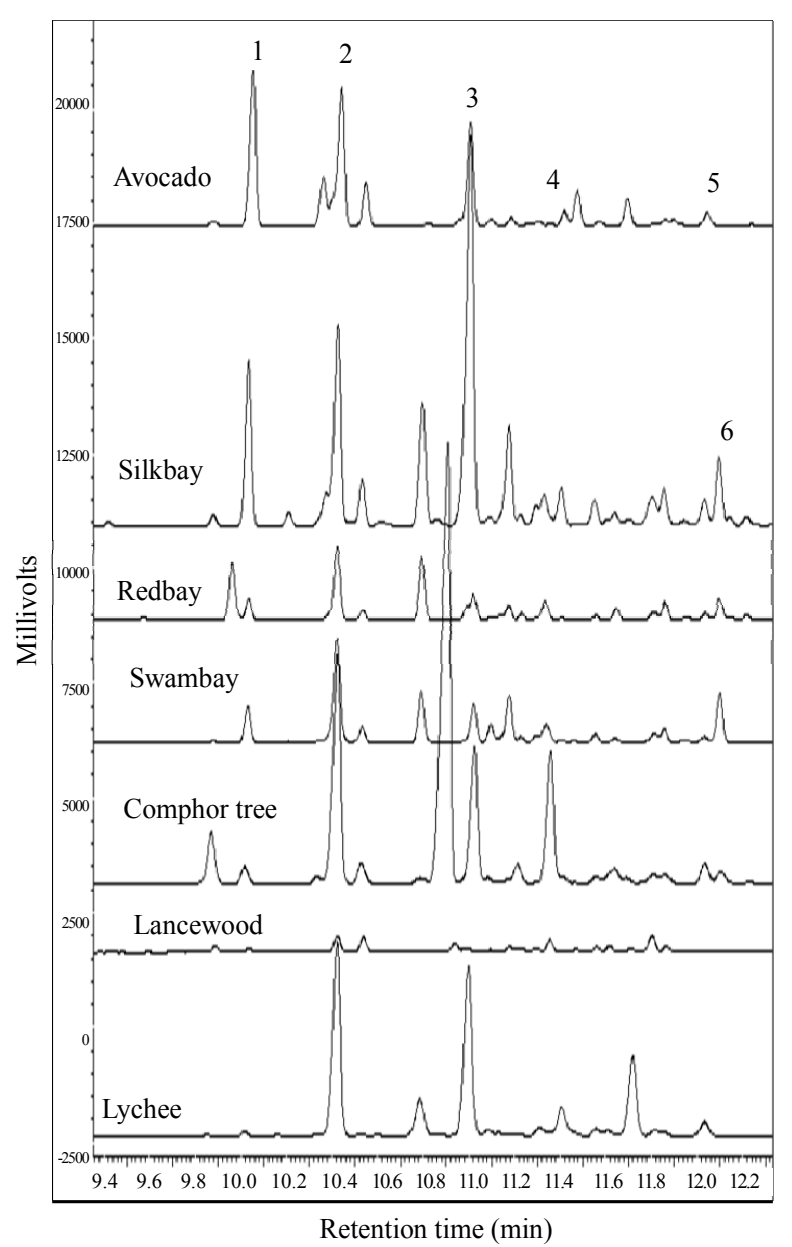

Figure 5. Gas chromatography-mass spectroscopy (GC-MS) analyses of volatile sesquiterpenes emitted from wood of six species of Lauraceae (avocado Persea americana, silkbay Persea humilis, redbay Persea borbonia, swampbay Persea palustris, camphor tree Cinnamomum camphora, and lancewood Ocotea coriacea) and from one species of Sapindaceae (lychee Litchi chinensis), a non-host tree highly attractive to female Xyleborus glabratus [50]. Volatiles were collected by Super $Q$ adsorbant. Common chemical constituents: $1 \alpha$-cubebene, $2 \alpha$-copaene, $3 \beta$-caryophyllene, 4 $\alpha$-humulene, $5 \delta$-cadinene, 6 calamenene. (Adapted from Niogret et al., 2011 [61]).

feasible. Many sesquiterpenes, particularly $\alpha$-copaene, are expensive and difficult to obtain in quantities sufficient for trap deployment [63]. Therefore, it is still a high priority to identify natural sources - such as plant essential oils - that are high in key attractive sesquiterpenes but may have longer field life than the current manuka oil lure. In a recent field test comparing seven essential oils (Figure 7), it was found that cubeb oil [a steam distillate from the berries of Piper cubeba L. (Piperaceae)] was just as attractive to dispersing $X$. glabratus as fresh manuka and phoebe oils. Tests are ongoing to further

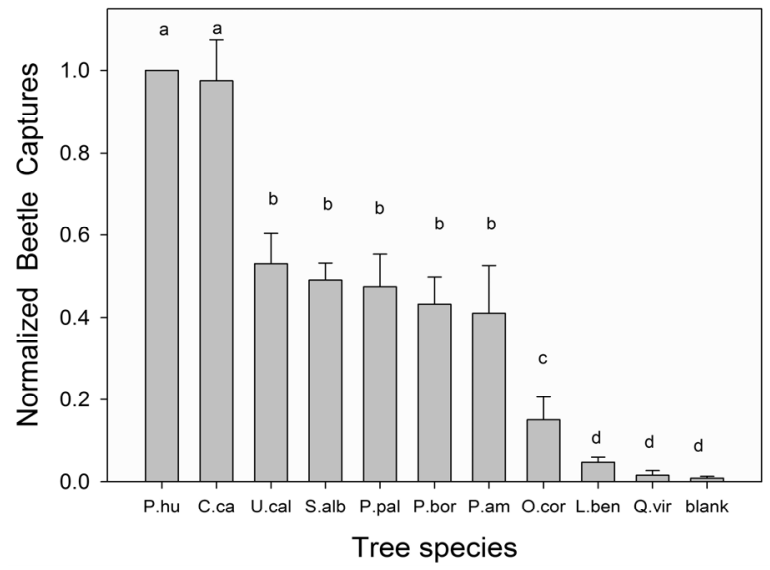

Figure 6. Relative attraction of female Xyleborus glabratus to nine species of Lauraceae, as indicated by field captures with sticky panel traps baited with wood bolts. Treatments consisted of silkbay Persea humilis, camphor tree Cinnamomum camphora, California bay laurel Umbellularia californica, sassafras Sassafras albidum, swampbay Persea palustris, redbay Persea borbonia, avocado Persea americana, lancewood Ocotea coriacea, northern spicebush Lindera benzoin, live oak Quercus virginiana (a non-host control), and a blank (an unbaited sticky panel; negative control). Graph presents composite results from several replicated field tests conducted in south-central Florida (Highlands County); therefore, to facilitate comparison, mean beetle captures were normalized by converting to percentages relative to silkbay, the species most attractive to $X$. glabratus, and used as a positive control in each test (Field tests were conducted using methods published previously by Kendra et al., 2011 [50]).

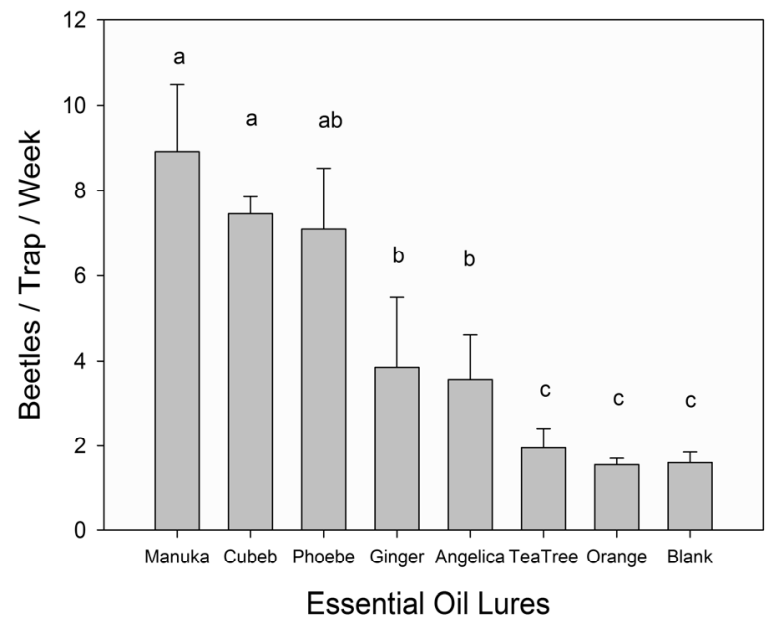

Figure 7. Captures (mean \pm S.E.) of female Xyleborus glabratus with essential oil lures deployed in sticky panel traps in a four week field test conducted in south-central Florida (Highlands County). A membrane-based dispenser [64] was used to prepare the lures, and each lure was loaded with $5 \mathrm{ml}$ of neat essential oil (Field test was conducted using methods published previously by Kendra et al., 2012 [58]). 
evaluate cubeb oil as a potential new attractant for $X$. glabratus.

\section{Conclusion}

Laurel wilt is firmly established within the southeastern United States, and its geographic range continues to expand. Research indicates that conditions are favorable for establishment of the disease along the US Pacific Coast, and there are numerous species of Lauraceae potentially at risk in Mexico, Central and South America, and throughout the Caribbean Basin. Due to the economic threat posed to avocado, disease management strategies are now under development, but no highly efficacious and cost-effective measure has been identified. It is apparent that a holistic approach is warranted, and will require a better understanding of the complex ecological and physiological interactions among the insect vector(s), the fungal symbiont, and susceptible host trees. Updated information on diverse topics related to laurel wilt disease can be found at websites maintained by the Florida Department of Agriculture and Consumer Services [42] and the Southern Region of the USDA Forest Service [65].

\section{Acknowledgements}

This work was supported in part by the USDA-ARS National Plant Disease Recovery System, a USDA National Institute of Food and Agriculture Critical Issues Grant, and the Florida Avocado Administrative Committee.

\section{REFERENCES}

[1] S. W. Fraedrich, T. C. Harrington, R. J. Rabaglia, M. D. Ulyshen, A. E. Mayfield III, J. L. Hanula, J. M. Eickwort, and D. R. Miller, "A Fungal Symbiont of the Redbay Ambrosia Beetle Causes a Lethal Wilt in Redbay and Other Lauraceae in the Southeastern United States," Plant Disease, Vol. 92, No. 2, 2008, pp. 215-224. doi/10.1094/PDIS-92-2-0215

[2] A. E. Mayfield III, J. E. Peña, J. H. Crane, J. A. Smith, C. L. Branch, E. D. Ottoson and M. Hughes, "Ability of the Redbay Ambrosia Beetle (Coleoptera: Curculionidae: Scolytinae) to Bore into Young Avocado (Lauraceae) Plants and Transmit the Laurel Wilt Pathogen (Raffaelea sp.)," Florida Entomologist, Vol. 91, 2008, pp. 485-487.

[3] R. C. Ploetz, J. M. Pérez-Martínez, J. A. Smith, M. Hughes, T. J. Dreaden, S. A. Inch and Y. Fu, "Responses of Avocado to Laurel Wilt, Caused by Raffaelea lauricola," Plant Pathology, Vol. 61, No. 4, 2012, pp. 801-806. doi/10.1111/j.1365-3059.2011.02564.x

[4] Florida Department of Agriculture and Consumer Services, "FDACS Identifies Laurel Wilt Disease in Avocado Production Area of Miami-Dade County, Press Release 1 May 2012," 2012.

http://www.freshfromflorida.com/newsroom/press/2012/0 5012012.html

[5] T. C. Harrington, S. W. Fraedrich and D. N. Aghayeva, "Raffaelea lauricola, a New Ambrosia Beetle Symbiont and Pathogen on the Lauraceae," Mycotaxon, Vol. 104, 2008, pp. 399-404.

[6] J. L. Hanula, A. E. Mayfield III, S. W. Fraedrich and R. J. Rabaglia, "Biology and Host Associations of the Redbay Ambrosia Beetle (Coleoptera: Curculionidae: Scolytinae), Exotic Vector of Laurel Wilt Killing Redbay Trees in the Southeastern United States," Journal of Economic Entomology, Vol. 101, No. 4, 2008, pp. 1276-1286. doi/10.1603/0022-0493(2008)101[1276:BAHAOR]2.0.C $\underline{\mathrm{O} ; 2}$

[7] R. J. Rabaglia, "XVII. Scolytinae Latreille 1807," In: R. H. Arnett, Jr., M. C. Thomas, P. E. Skelley and J. H. Frank, Eds., American Beetles, Vol. 2, Polyphaga: Scarabaeoidea through Curculionoidea, CRC Press, Boca Raton, 2002, pp. 792-805.

[8] R. A. Haack, "Intercepted Scolytidae (Coleoptera) at US Ports of Entry: 1985-2000," Integrated Pest Management Reviews, Vol. 6, No. 3-4, 2001, pp. 253-282.

doi/10.1023/A:1025715200538

[9] J. E. Aukema, D. G. McCullough, B. V. Holle, A. M. Liebhold, K. Britton and S. J. Frankel, "Historical Accumulation of Non-Indigenous Forest Pests in the Continental United States," Bioscience, Vol. 60, No. 11, 2010, pp. 886-897. doi/10.1525/bio.2010.60.11.5

[10] J. Hulcr and R. R. Dunn, "The Sudden Emergence of Pathogenicity in Insect-Fungus Symbioses Threatens Naïve Forest Ecosystems," Proceedings of the Royal Society $B$, Vol. 278, No. 1720, 2011, pp. 2866-2873. doi/10.1098/rspb.2011.1130

[11] A. E. Mayfield III and M. C. Thomas, "FDACS Pest Alert: The Redbay Ambrosia Beetle, Xyleborus glabratus Eichhoff (Scolytinae: Curculionidae)," 2009. http://www.freshfromflorida.com/pi/pest-alert/xyleborusglabratus.html

[12] R. A. Beaver and L.Y. Liu, "An Annotated Synopsis of Taiwanese Bark and Ambrosia Beetles, with New Synonymy, New Combinations and New Records (Coleoptera: Curculionidae: Scolytinae)," Zootaxa, Vol. 2602, 2010, pp. 1-47.

[13] R. J. Rabaglia, S. A. Dole and A. I. Cognato, "Review of American Xyleborina (Coleoptera: Curculionidae: Scolyinae) Occurring North of Mexico, with an Illustrated Key," Annals of the Entomological Society of America, Vol. 99, No. 6, 2006, pp. 1034-1056. doi/10.1603/0013-8746(2006)99[1034:ROAXCC]2.0.CO ;2

[14] F. H. Koch and W. D. Smith, "Spatio-Temporal Analysis of Xyleborus glabratus (Coleoptera: Curculionidae: Scolyinae) Invation in Eastern US Forests," Environmental Entomology, Vol. 37, No. 2, 2008, pp. 442-452. doi/10.1603/0046-225X(2008)37[442:SAOXGC]2.0.CO; $\underline{2}$

[15] Florida Department of Agriculture and Consumer Services, Division of Plant Industry, "Firewood Movement Rule (5B-65)," 2010. 
http://www.freshfromflorida.com/pi/firewood/

[16] Florida Department of Agriculture and Consumer Services, "Laurel Wilt Disease Identified in Miami-Dade County, Press Release 25 February 2011," 2011. http://www.freshfromflorida.com/press/2011/02252011.ht $\mathrm{ml}$

[17] United States Department of Agriculture, Forest Service, Forest Health Protection, Southern Region, "Laurel Wilt Distribution," 2012.

http://www.fs.fed.us/r8/foresthealth/laurelwilt/dist_map.s html

[18] R. C. Ploetz, T. Harrington, J. Hulcr, R. Bostock, A. Eskalen, B. Farber, J. Crane, C. Harmon, S. Inch, A. Palmateer, J. Peña, J. Smith, P. Kendra, R. Schnell, S. Fraedrich, J. Hanula, A. Mayfield, R. Rabaglia and M. Wingfield, "Recovery Plan for Laurel Wilt of Avocado," US National Plant Disease Recovery System, 2011. http://www.ars.usda.gov/SP2UserFiles/Place/00000000/o pmp/Avocado\%20LW\%20110829.pdf

[19] A. E. Mayfield III, E. Barnard, T. Harrington, S. Fraedrich, J. Hanula, V. Vankus, R. Rabaglia, R. Duerr, R. Bulluch, L. Johnson, C. Bates, S. Cameron, J. Smith, J. Peña, F. Campbell and A. Boone, "Recovery Plan for Laurel Wilt on Redbay and Other Forest Species," US National Plant Disease Recovery System, 2009. http:/www.ars.usda.gov/SP2UserFiles/Place/00000000/o pmp/ForestLaurelWilt100107.pdf

[20] P. E. Kendra, W. S. Montgomery, J. Niogret, M. A. Deyrup, L. Guillén and N. D. Epsky, "Xyleborus glabratus, $X$. affinis, and $X$. ferrugineus (Coleoptera: Curculionidae: Scolytinae): Electroantennogram Responses to Host-Based Attractants and Temporal Patterns in HostSeeking Flight," Environmental Entomology, Vol. 41, 2012, pp. 1597-1605. doi/10.1603/EN12164

[21] G. S. Brar, J. L. Capinera, S. McLean, P. E. Kendra, R. C. Ploetz and J. E. Peña, "Effect of Trap Size, Trap Height, and Age of Lure on Sampling Xyleborus glabratus (Coleoptera: Curculionidae: Scolytinae), and its Flight Periodicity and Seasonality," Florida Entomologist, Vol. 95, 2012, pp. 1003-1011.

[22] G. S. Brar, "Ecology and Biology of Redbay Ambrosia Beetle (Xyleborus glabratus Eichhoff)," Ph.D. Dissertation, University of Florida, Gainesville, 2012.

[23] P. E. Kendra, J. S. Sanchez, W. S. Montgomery, K. E. Okins, J. Niogret, J. E. Peña, N. D. Epsky and R. R. Heath, "Diversity of Scolytinae (Coleoptera: Curculionidae) Attracted to Avocado, Lychee, and Essential Oil Lures," Florida Entomologist, Vol. 94, No. 2, 2011, pp. 123-130. doi:10.1653/024.094.0201

[24] D. Carrillo, R. E. Duncan and J. E. Peña, “Ambrosia Beetles (Coleoptera: Curculionidae: Scolytinae) that Breed in Avocado Wood in Florida," Florida Entomologist, Vol. 95, No. 3, 2012, pp. 573-579.

[25] H. Gebhardt, D. Begerow, and F. Oberwinkler, "Identification of the Ambrosia Fungus of Xyleborus monographus and $X$. dryographus (Coleoptera: Curculionidae, Scolytinae)," Mycological Progress, Vol. 3, No. 2, 2004, pp. 95-102. doi/10.1007/s11557-006-0080-1
[26] J. A. Morales-Ramos, M. G. Rojas, H. Sittertz-Bhatkar and G. Saldaña, "Symbiotic Relationship Between $H y$ pothenemus hampei (Coleoptera: Scolytidae) and Fusarium solani (Moniliales: Tuberculariaceae)," Annals of the Entomological Society of America, Vol. 93, 2000, pp. 541-547.

[27] S. W. Fraedrich, T. C. Harrington, C. A. Bates, J. Johnson, L. S. Reid, G. S. Best, T. D. Leininger and T. S. Hawkins, "Susceptibility to Laurel Wilt and Disease Incidence in Two Rare Plant Species, Pondberry and Pondspice," Plant Disease, Vol. 95, No. 9, 2011, pp. 1056-1062. doi/10.1094/PDIS-11-10-0841

[28] T. C. Harrington and S. W. Fraedrich, "Quantification of Propagules of the Laurel Wilt Fungus and Other Mycangial Fungi from the Redbay Ambrosia Beetle, Xyleborus glabratus," Phytopathology, Vol. 100, No. 10, 2010, pp. 1118-1123. doi/10.1094/PHYTO-01-10-0032

[29] T. C. Harrington, H. Y. Yun, S. S. Lu, H. Goto, D. N. Aghayeva and S. W. Fraedrich, "Isolations from the Redbay Ambrosia Beetle, Xyleborus glabratus, Confirm that the Laurel Wilt Pathogen, Raffaelea lauricola, Originated in Asia," Mycologia, Vol. 103, No. 5, 2011, pp. 1028 1036. doi:10.3852/10-417

[30] S. M. Alamouti, C. K. M. Tsui and C. Breuil, "Multigene Phylogeny of Filamentous Ambrosia Fungi associated with Ambrosia and Bark Beetles," Mycological Research, Vol. 113, No. 8, 2009, pp. 822-835. doi:10.1016/j.mycres.2009.03.003

[31] T. C. Harrington, D. N. Aghayeva and S. W. Fraedrich, "New Combinations of Raffaelea, Ambrosiella, and Hyalorhinocladiella, and Four New Species from the Redbay Ambrosia Beetle, Xyleborus glabratus," Mycotaxon, Vol. 111, 2010, pp. 337-361. doi:10.5248/111.337

[32] L. R. Batra, "Ambrosia Fungi: A Taxonomic Revision and Nutritional Studies of Some Species," Mycologia, Vol. 59, No. 6, 1967, pp. 976-1017. doi:10.2307/3757271

[33] J. Hulcr, R. Mann and L. L. Stelinski, "The Scent of a Partner: Ambrosia Beetles are Attracted to Volatiles from their Fungal Symbionts," Journal of Chemical Ecology, Vol. 37, No. 12, 2011, pp. 1374-1377. doi:10.1007/s10886-011-0046-X

[34] S. Inch, R. Ploetz, B. Held and R. Blanchette, "Histological and Anatomical Responses in Avocado, Persea ameriana, Induced by the Vascular Wilt Pathogen, Raffaelea lauricola," Botany, Vol. 90, No. 7, 2012, pp. 627 635. doi:10.1139/b2012-015

[35] A. E. Mayfield III and J. L. Hanula, "Effect of Tree Species and End Seal on Attractiveness and Utility of Cut Bolts to the Redbay Ambrosia Beetle and Granulate Ambrosia Beetle (Coleoptera: Curculionidae: Scolytinae)," Journal of Economic Entomology, Vol. 105, No. 2, 2012, pp. 461-470. doi:10.1603/EC11348

[36] A. E. Mayfield III, M. MacKenzie, P. G. Cannon, S. W. Oak, S. Horn, J. Hwang and P. E. Kendra, "Suitability of California Bay Laurel and Other Species as Hosts for the Non-Native Redbay Ambrosia Beetle and Granulate Ambrosia Beetle," Agricultural and Forest Entomology, 2013, In Press. 
[37] J. E. Peña, D. Carrillo, R. E. Duncan, J. L. Capinera, G. Brar, S. McLean, M. L. Arpaia, E. Focht, J. A. Smith, M. Hughes and P. E. Kendra, "Susceptibility of Persea spp. And Other Lauraceae to Attack by Redbay Ambrosia Beetle, Xyleborus glabratus (Coleoptera: Curculionidae: Scolyinae)," Florida Entomologist, Vol. 95, 2012, pp. 783-787.

[38] S. W. Fraedrich, T. C. Harrington and R. J. Rabaglia, "Laurel Wilt: A New and Devastating Disease of Redbay Caused by a Fungal Symbiont of the Exotic Redbay Ambrosia Beetle," Newsletter of the Michigan Entomological Society, Vol. 52, 2007, pp. 14-15.

[39] J. M. Scriber, N. Margraf and T. Wells, "Suitability of Four Families of Florida 'Bay' Species for Papilio palamedes and P. glaucus (Papilionidae)," Journal of the Lepidopterists' Society, Vol. 54, 2000, pp. 131-136.

[40] K. D. Coder, "Redbay (Persea borbonia): A Tree of Confusion," Outreach Publication SFNR06-3, Warnell School of Forestry and Natural Resources, University of Georgia, 2006.

http://www.urbanforestrysouth.org/resources/library/redb ay-persea-borbonia-a-tree-of-confusion/file_name

[41] United States Department of Agriculture, National Agricultural Statistic Service, "Noncitrus Fruits and Nuts: 2010 Preliminary Summary," 2011.

http://usda.mannlib.cornell.edu/usda/current/NoncFruiNu/ NoncFruiNu-01-2102011.pdf

[42] Florida Department of Agriculture and Consumer Services, "Laurel Wilt," 2004.

http://www.freshfromflorida.com/pi/enpp/pathology/laure 1_wilt_disease.html

[43] S. W. Fraedrich, "California Laurel is Susceptible to Laurel Wilt Caused by Raffaelea lauricola," Plant Disease, Vol. 92, No. 10, 2008, p. 1469. doi:10.1094/PDIS-92-10-1469A

[44] J. E. Peña, J. H. Crane, J. L. Capinera, R. E. Duncan, P. E. Kendra, R. C. Ploetz, S. Mclean, G. Brar, M. C. Thomas and R. D. Cave, "Chemical Control of the Redbay Ambrosia Beetle, Xyleborus glabratus, and Other Scolytinae (Coleoptera: Curculionidae)," Florida Entomologist, Vol. 94, 2011, pp. 882-896.

[45] A. E. Mayfield III, L. E. Barnard, J. A. Smith, S. C. Bernick, J. M. Eickwort and T. J. Dreaden, "Effect of Propiconazole on Laurel Wilt Disease Development in Redbay Trees and on the Pathogen In Vitro," Arboriculture and Urban Forestry, Vol. 34, 2008, pp. 317-324.

[46] R. C. Ploetz, J. M. Pérez-Martínez, E. A. Evans and S. A. Inch, "Towards Fungicidal Management of Laurel Wilt of Avocado," Plant Disease, Vol. 95, 2011, pp. 977-982.

[47] R. J. Stipes, "The Management of Dutch Elm Disease," In: C. E. Dunn, Ed., The Elms: Breeding, Conservation, and Disease Management, Kluwer Academic Publishers, Boston, 2000, pp. 157-172.

[48] R. J. Scheffer, J. G. W. F. Voeten and R. P. Guries, "Biological Control of Dutch Elm Disease," Plant Disease, Vol. 92, No. 2, 2008, pp. 192-200. doi:10.1094/PDIS-92-2-0192

[49] K. C. Shin, M. Hughes, J. A. Smith and R. C. Ploetz,
"Laurel Wilt on Redbay, Persea borbonia: Distinct Communities of Endophytic Fungi in Diseased and Healthy Trees," The International Forestry Review, Vol. 12, 2010, p. 398.

[50] P. E. Kendra, W. S. Montgomery, J. Niogret, J. E. Peña, J. L. Capinera, G. Brar, N. D. Epsky and R. R. Heath, "Attraction of the Redbay Ambrosia Beetle, Xyleborus glabratus, to Avocado, Lychee, and Essential Oil Lures," Journal of Chemical Ecology, Vol. 37, 2011, pp. 932-942.

[51] R. C. Ploetz, J. M. Pérez-Martínez, J. M. Smith and M. Hughes, "Laurel Wilt of Avocado: Assessing Genotypic Responses, Factors that Influence Disease Development, and the Potential for Management with Fungicides," The International Forestry Review, Vol. 12, 2010, p. 398.

[52] United States Department of Agriculture, Agricultural Research Service, "Research Project: Screening Avocado (Persea americana) Germplasm for Tolerance/Resistance to the Laurel Wilt Pathogen (Raffaelea lauricola)," 2013. http://www.ars.usda.gov/research/projects/projects.htm?A CCN_NO=419974

[53] R. C. Ploetz, S. A. Inch, J. M. Pérez-Martínez and T. L. White, Jr., "Systemic Infection of Avocado, Persea americana, by Raffaelea lauricola, Does Not Progress into Fruit Pulp or Seed," Journal of Phytopathology, Vol. 160, No. 9, 2012, pp. 491-495. doi:10.1111/j.1439-0434.2012.01930.x

[54] J. L. Hanula, M. D. Ulyshen and S. Horn, "Effect of Trap Type, Trap Position, Time of Year, and Beetle Density on Captures of the Redbay Ambrosia Beetle (Coleoptera: Curculionidae: Scolytinae)," Journal of Economic Entomology, Vol. 104, No. 2, 2011, pp. 501-508. doi:10.1603/EC10263

[55] D. R. Miller and R. J. Rabaglia, "Ethanol and (-)- $\alpha-$ Pinene: Attractant Kairomones for Bark and Ambrosia Beetles in the Southeastern US," Journal of Chemical Ecology, Vol. 35, No. 4, pp. 435-448. doi:10.1007/s10886-009-9613-9

[56] P. E. Kendra, W. S. Montgomery, J. S. Sanchez, M. A. Deyrup, J. Niogret and N. D. Epsky, "Method for Collection of Live Redbay Ambrosia Beetles, Xyleborus glabratus (Coleoptera: Curculionidae: Scolytinae)," Florida Entomologist, Vol. 95, 2012, pp. 510-513.

[57] J. L. Hanula and B. Sullivan, "Manuka Oil and Phoebe Oil are Attractive Baits for Xyleborus glabratus (Coleoptera: Curculionidae: Scolytinae), the Vector of Laurel Wilt," Environmental Entomology, Vol. 37, No. 6, 2008, pp. 1403-1409. doi:10.1603/0046-225X-37.6.1403

[58] P. E. Kendra, J. Niogret, W. S. Montgomery, J. S. Sanchez, M. A. Deyrup, G. E. Pruett, R. C. Ploetz, N. D. Epsky and R. R. Heath, "Temporal Analysis of Sesquiterpene Emissions from Manuka and Phoebe Oil Lures and Efficacy for Attraction of Xyleborus glabratus (Coleoptera: Curculionidae: Scolyinae)," Journal of Economic Entomology, Vol. 105, No. 2, 2012, pp. 659-669. doi:10.1603/EC11398

[59] B. S. Lindgren, "A Multiple Funnel Trap for Scolytid Beetles (Coleoptera)," Canadian Entomologist, Vol. 115, No. 3, 1983, pp. 299-302. doi:10.4039/Ent115299-3 
[60] Center for Invasive Species and Ecosystem Health, "Forestry Images, Lindgren Funnel Trap," 2010.

http://www.forestryimages.org/browse/detail.cfm?imgnu $\mathrm{m}=5426963$

[61] J. Niogret, P. E. Kendra, N. D. Epsky and R. R. Heath, "Comparative Analysis of Terpenoid Emissions from Florida Host Trees of the Redbay Ambrosia Beetle, $X y$ leborus glabratus (Coleoptera: Curculionidae: Scolytinae)," Florida Entomologist, Vol. 94, No. 4, 2011, pp. 1010-1017. doi:10.1653/024.094.0439

[62] J. Niogret, W. S. Montgomery, P. E. Kendra, R. R. Heath and N. D. Epsky, "Attraction and Electroantennogram Responses of Male Mediterranean Fruit Fly to Volatile Chemicals from Persea, Litchi, and Ficus Wood," Journal of Chemical Ecology, Vol. 37, No. 5, 2011, pp. 483491. doi:10.1007/s10886-011-9953-0

[63] R. A. Flath, R. T. Cunningham, T. R. Mon and J. O. John,
"Male Lures for Mediterranean Fruit Fly (Ceratitis capitata Wied.): Structural Analogs of $\alpha$-Copaene," Journal of Chemical Ecology, Vol. 20, No. 10, 1994, pp. 25952609. doi:10.1007/BF02036194

[64] P. E. Kendra, N. D. Epsky, W. S. Montgomery and R. R. Heath, "Response of Anastrepha suspensa (Diptera: Tephritidae) to Terminal Diamines in a Food-Based Synthetic Attractant," Environmental Entomology, Vol. 37, No. 5, 2008, pp. 1119-1125. doi:10.1603/0046-225X(2008)37[1119:ROASDT]2.0.CO ;2

[65] United States Department of Agriculture, Forest Service, Forest Health Protection, Southern Region, "Laurel Wilt," 2012.

http://www.fs.fed.us/r8/foresthealth/laurelwilt/index.shtm 1 